\title{
Sensory changes related to breeding for plant architecture and resistance to viruses and anthracnose in bean market class Fabada (Phaseolus vulgaris L.)
}

\author{
J. J. Ferreira $\cdot$ Romero R. del Castillo • \\ E. Perez-Vega $\cdot$ M. Plans $\cdot$ J. Simó $\cdot$ F. Casañas
}

Received: 5 May 2011/Accepted: 16 September 2011/Published online: 15 October 2011

(C) Springer Science+Business Media B.V. 2011

\begin{abstract}
Consumers hold landraces in high esteem and often consider that breeding programs lead to a loss of sensory quality, although consumers' opinions have not been scientifically confirmed. As a model case of study we recorded seed sensory traits in six inbred common bean lines classified in the market class Fabada obtained by backcrossing and/or pedigree selection (to change the plant architecture and increase resistances) and then cultivated in two environments in two consecutive years. A sensory panel noted differences among all the inbreds, but only the introduction of the gene fin (determinate growth habit) seemed to be associated to a loss of quality (rougher seed coat and lower percentage of whole beans after cooking). As theoretically expected, changes in sensory traits were smaller in inbreds obtained through simple backcrossing than in those obtained through pedigree selection after inbred crossing. Large differences in sensory traits due to environmental factors were also recorded (similar to the genetic effects in magnitude), especially soil type and rainfall around flowering. These results make it
\end{abstract}

J. J. Ferreira - E. Perez-Vega

Área de Cultivos Hortofrutícolas y Forestales, SERIDA, Apdo. 13, 33300 Villaviciosa, Asturias, Spain

R. R. del Castillo · M. Plans · J. Simó · F. Casañas $\mathrm{DEAB}$, Departament d'Enginyeria Agroalimentària i Biotecnologia, Escola Superior d'Agricultura de Barcelona, Campus Baix Llobregat, Edifici D4,UPC, 08860 Castelldefels, Spain highly recommendable to evaluate sensory attributes in the course of breeding programs to ensure that the sensory quality is not lost. Given the importance of the environmental component in the phenotypic variation of the sensory traits studied, crop location and management also appear as key factors for the obtainment of optimum products.

Keywords Sensory analysis - Culinary traits . Common beans $\cdot$ Breeding process $\cdot$ Loss of quality

\section{Introduction}

Diminished sensory quality (texture and flavor) and culinary value of vegetables in recent years is usually attributed to breeding for agronomic traits, external sensory traits (color, shape, uniformity), and postharvest preservation (Van Ruth et al. 1995).

Although there is wide genetic variability for sensory traits, environmental factors also exert strong influences on them. Consumers' appreciation of unique combinations of variety and location is reflected in the Protected Designation of Origin legal framework, which recognizes the importance of both these effects and the interaction between them. Studies carried out in diverse species have found significant variety and location effects for sensory attributes (Bhattacharjee et al. 2002; Florez et al. 2009; Hoberg et al. 2003; Labuschagne et al. 
2004; Schonhof et al. 2004). However, little is known about environmental effects in the variability of culinary traits.

Although some Mendelian genes that control internal sensory traits of plant products have been identified (Jin et al. 2009), these traits are normally quantitative and involve loci with pleiotropic effects (Chaib et al. 2006; Lecomte et al. 2004; Marsh et al. 2003; Oraguzie et al. 2003).

Consumers, especially in Europe, tend to complain about genetically improved products derived from landraces renowned for their sensory quality (Guerrero et al. 2009). Over more than 20 years' working on bean genetic resources, we have noticed that this belief is so firmly established that consumers often reject beans from near-isogenic lines with determinate growth derived from plants with indeterminate growth. Likewise, consumers prefer unimproved traditional varieties of beans to the same varieties after breeding for resistance to disease or pests. However, these preferences are not based on a detailed analysis of the beans' sensory traits before and after the breeding program; thus, the extent to which these beliefs are due to prejudices remains to be determined. On the other hand, because scientific sensory evaluation is difficult and expensive, it is rarely incorporated into breeding programs aimed at improving resistance or plant architecture, especially during the intermediate steps.

The prestigious Fabada market class of beans (Voysest 2000) has an extreme seed phenotype consisting of very large (90-100 g/100 seeds), oblong, white seeds. Landraces with this seed phenotype have an indeterminate growth habit and are susceptible to bean pathogens like anthracnose and bean common mosaic virus (BCMV) that are frequent in their traditional area of cultivation (Asturias, north of Spain). In recent years, different breeding programs have aimed to introgress determinate growth habit and resistance to local races of anthracnose (Colletotrichum lindemuthianum (Sacc. \& Magnus) Lams.Scrib) and BCMV into this market class to favor its agronomic management.

We aimed to: (i) investigate possible genetic changes in sensory and culinary traits occurring during the breeding process to obtain new inbred lines with seed phenotypes classified in the Fabada market class, and (ii) analyze environmental effects in the expression of those traits.

\section{Materials and methods}

\section{Plant materials}

We analyzed six inbred lines of Andean origin (PerezVega 2010) (Fig. 1) classified in the market class Fabada (Voysest 2000): lines A25, A2418, and A2806 with indeterminate growth habit and lines Xana, $\mathrm{X} 1319$, and X1358 with determinate growth habit. All six lines yield large (about 85 g per 100 seeds) white seeds.
Fig. 1 Pedigree of the six breeding lines classified in the market class Fabda used in the study. $B c$, backcross method; $S c$, pedigree method from single crosses. Co-resistance gene to anthracnose; I, $b c-3$, resistance genes to bean common mosaic virus

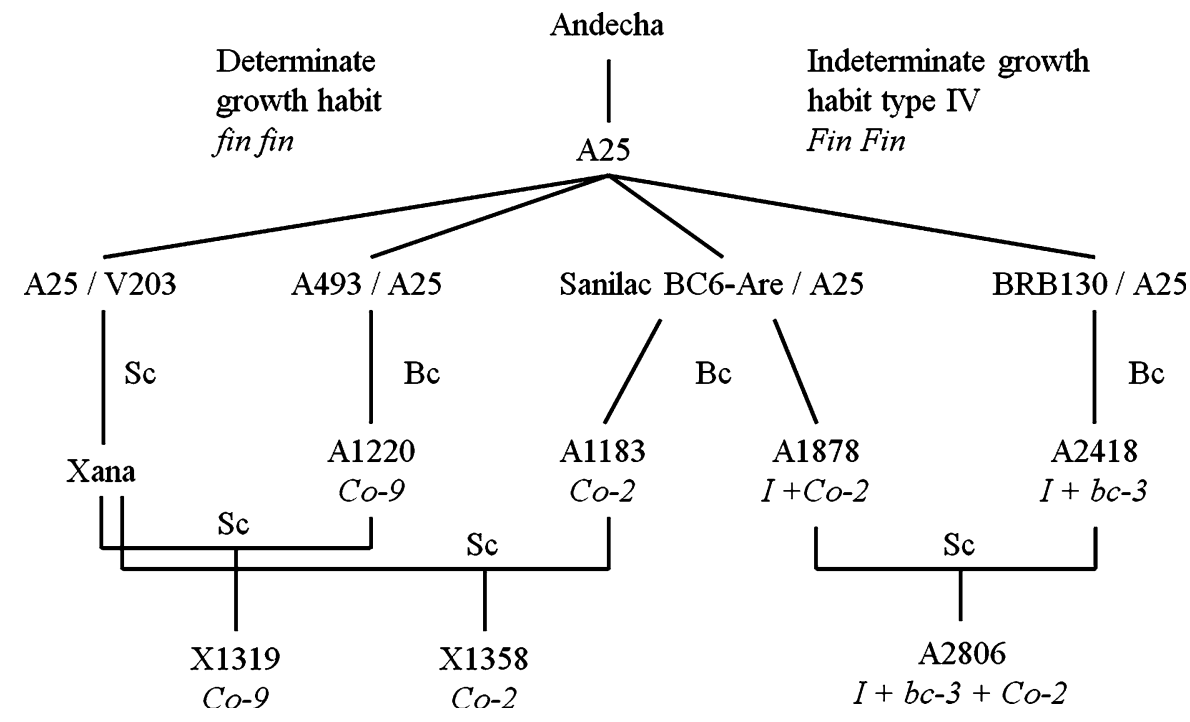


Line A25 was obtained from the cultivar Andecha (Fig. 1) using seed phenotype as the selection criterion and is considered to be the reference for standard commercial Fabada beans. Andecha is a very large white-seeded cultivar classified in the market class Fabada, and it has a type IV indeterminate growth habit (Singh 1982). Line A25 was used as the recurrent parent in the backcross breeding programs developed at SERIDA (Villaviciosa, Asturias, Spain) to introgress genetic resistance to local races of anthracnose and a strain of BCMV. In a first step, single resistance genes to anthracnose and BCMV were introgressed into line A25 by backcrossing (Fehr 1987) from resistance sources A493, Sanilac BC6-Are, and BRB130. The breeding programs included six backcross generations followed by four self-pollinated generations (Fig. 1).

The donor line A493 ('Alubia'/'BAT93') used in the development of new line A1220 has a wide spectrum of resistance to anthracnose, including the local races (Ferreira et al. 2007; Menezes and Dianese 1988), and a seed phenotype classified in the market class Alubia (Voysest 2000).

The donor line Sanilac BC6-Are, used in the obtainment of lines A1878 and A1183, was developed from a backcross breeding program using the cultivar Cornell 49242 as the donor of the resistance allele to anthracnose $\mathrm{Co}-2$ and the Navy market class bean Sanilac as the recurrent parent (Aylesworth et al. 1983). Cultivar Sanilac BC6-Are also has genetic resistance to BCMV conferred by a dominant gene.

The donor line BRB130 developed in CIAT, used in the obtainment of line A2418, is a white-seeded line with alleles $I+b c-3$ that confer resistance to all known strains of BCMV (Mendez-Vigo et al. 2005). In a second step, different resistance genes were pyramided (Fig. 1) from single crosses followed by four selfpollinated generations using seed phenotype and resistance to both pathogens as selection criteria in each generation (Fig. 1). By this method, line A2806 including resistance to anthracnose (genotype $\mathrm{Co}-2$ ) and BCMV (genotype $I+b c-3$ ) was obtained.

In another, parallel breeding program (Fig. 1), determinate growth habit was introgressed in line A25 from a single cross between line A25 and the accession V203, a local landrace with determinate growth habit type I (Singh 1982) classified in the Canellini market class (Voysest 2000). The line Xana was obtained using a pedigree method (Fehr 1987) with self-pollinated generations and individual selection. Resistance to local races of anthracnose was introgressed into Xana from the indeterminate lines A1220 and A1183 through single crosses following five self-pollinated generations and individual selection. This process allowed the obtainment of lines X1358 and X1319 (Fig. 1). As indicated above, lines A1220 and A1183 were derived through a backcross program carried out to introgress genetic resistance to anthracnose in line A25 from the resistance sources A493 and Sanilac BC6-Are, respectively.

Field trials

Trials were carried out in 2006 and 2007 in Villaviciosa, $43^{\circ} 29^{\prime} 01^{\prime \prime} \mathrm{N}, 05^{\circ} 26^{\prime} 11^{\prime \prime} \mathrm{W}$, elevation $6.5 \mathrm{~m}$, and Argüelles, $43^{\circ} 26^{\prime} 06^{\prime \prime} \mathrm{N},{ }^{\circ} 03^{\prime} 39^{\prime \prime} \mathrm{W}$, elevation $180 \mathrm{~m}$. Both locations are in Asturias (north of Spain) and represent soil differences within the area of cultivation included in the Protected Geographical Indication "Faba Asturiana".

Asturias has a mean annual rainfall of $1000-15001 \mathrm{~m}^{-2}$ distributed unevenly throughout the year but mainly concentrated in the spring and autumn. Summer temperatures are generally moderate and beans do not require irrigation. In August 2006, the most critical month in the culture, rainfall was $11.4 \mathrm{~mm}$ and the temperature averaged $18.7^{\circ} \mathrm{C}$. In August 2007, rainfall was $100.5 \mathrm{~mm}$ and the temperature averaged $17.3^{\circ} \mathrm{C}$ (Fig. 2).

The $\mathrm{pH}$ of Asturian soils is about neutral, the proportion of organic matter is generally high, and textures vary between loamy clay and loamy sand (Table 1). The main differences between the experimental locations, which were chosen to represent the variation in Asturian soils, were related to $\mathrm{P}, \mathrm{Mg}$, and $\mathrm{K}$ content and to cationic exchange ability, which were all higher in Villaviciosa. The soil in Villaviciosa is also less sandy than in Argüelles (Table 1).

Experimental design and statistical analysis

We used a complete four randomized block design in each year and location, following the traditional management in the area. Plots consisted of three $4 \mathrm{~m}$ long rows with 25 plants per row and $1.2 \mathrm{~m}$ between rows.

ANOVA was performed using the SAS statistical package version 8.1 (SAS Institute Inc 1999). For the 
Fig. 2 Temperature and rainfall recorded at Oviedo station, near both experimental locations, during the period of culture in both experimental years

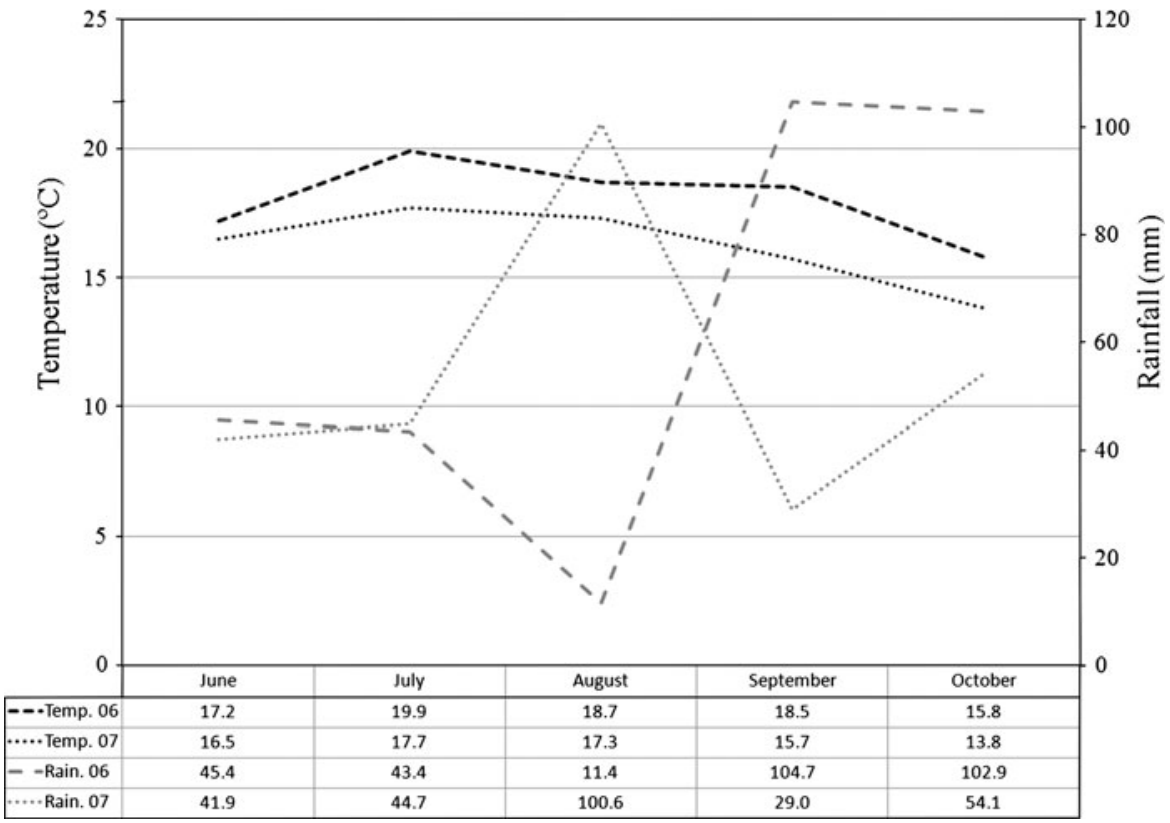

Table 1 Soil parameters in the locations Argüelles and Villaviciosa

\begin{tabular}{|c|c|c|}
\hline Soil parameters & Argüelles & Villaviciosa \\
\hline Water content $105^{\circ} \mathrm{C}\left(\mathrm{g} \mathrm{kg}^{-1}\right)$ & 2 & 25 \\
\hline $\mathrm{pH}$ (water) & 7.5 & 7.2 \\
\hline $\begin{array}{l}\text { Electrical conductivity } 25^{\circ} \mathrm{C} \\
(\mathrm{dS} / \mathrm{m})(1: 5)\end{array}$ & 0.64 & 0.44 \\
\hline Organic matter $\left(\mathrm{g} \mathrm{kg}^{-1}\right)$ & 26.9 & 37.5 \\
\hline $\mathrm{N}-\mathrm{NO}_{3} \mathrm{mg} \mathrm{N}-\mathrm{NO}_{3} / \mathrm{kg}$ & 74 & 69 \\
\hline P ASS.(Olsen) ppm & 20 & 97 \\
\hline K (Ex.Ac.Am.) ppm & 142 & 345 \\
\hline Mg (Ex.Ac.Am.) ppm & 31 & 191 \\
\hline Carbonate as $\mathrm{CaCO}_{3}\left(\mathrm{~g} \mathrm{~kg}^{-1}\right)$ & 30 & 20 \\
\hline $\mathrm{Ca}$ (Ex.Ac.Am.) ppm & 3288 & 2662 \\
\hline Na (Ex.Ac.Am.) ppm & 56 & 65 \\
\hline $\begin{array}{l}\text { Sand } 0.05<\mathrm{D}<2 \mathrm{~mm} \\
\quad\left(\mathrm{~g} \mathrm{~kg}^{-1}\right)\end{array}$ & 522 & 390 \\
\hline $\begin{array}{l}\text { Coarse silt } 0.02<\mathrm{D}<0.05 \\
\left(\mathrm{~g} \mathrm{~kg}^{-1}\right)\end{array}$ & 178 & 145 \\
\hline $\begin{array}{l}\text { Fine silt } 0.002<\mathrm{D}<0.02 \mathrm{~mm} \\
\quad(\mathrm{~g} \mathrm{~kg}-1)\end{array}$ & 122 & 260 \\
\hline Clay $\mathrm{D}<0.002 \mathrm{~mm}\left(\mathrm{~g} \mathrm{~kg}^{-1}\right)$ & 172 & 200 \\
\hline Textural class (USDA) & $\begin{array}{l}\text { Sandy clay } \\
\text { loam }\end{array}$ & $\begin{array}{l}\text { Sandy clay } \\
\text { loam }\end{array}$ \\
\hline Water content $33 \mathrm{kPa}\left(\mathrm{g} \mathrm{kg}^{-1}\right)$ & 100 & 190 \\
\hline Water content $1.5 \mathrm{MPa}\left(\mathrm{g} \mathrm{kg}^{-1}\right)$ & 60 & 110 \\
\hline $\begin{array}{l}\text { Cation exchange capacity } \\
\left(\mathrm{cmol} \mathrm{kg}^{-1}\right)\end{array}$ & 8.1 & 12.2 \\
\hline
\end{tabular}

culinary traits, we considered two fixed factors: location $(\lambda)$ and variety (v), and two random factors: year (y) and block (b), with the linear model: $\mathrm{x}_{\mathrm{ijklmn}}=\mu+\lambda_{\mathrm{i}}+v_{\mathrm{j}}+\mathrm{y}_{1}+\mathrm{b}_{\mathrm{m}(\mathrm{il})}+\lambda_{\mathrm{i}} v_{\mathrm{j}}+$ $\lambda_{\mathrm{i}} \mathrm{y}_{1}+v_{\mathrm{j}} \mathrm{y}_{1}+\mathrm{e}_{\mathrm{ijklmn}}$. For the sensory traits, the same model was used, replacing the block effect (b) within year and location, with the fixed effect panelist (p), as the seeds from the four blocks belonging to the same variety, location, and year were mixed for the sensory analysis. The interactions of the factor "panelist" with the other factors were also included in the linear model. Significant differences between means were established using the least significant difference test.

\section{Sample preparation}

After harvest and cleaning, the seeds were stored at $4^{\circ} \mathrm{C}$ until the sensory analyses were carried out. Seeds were prepared using the protocol described by Romero del Castillo et al. (Romero del Castillo et al. 2008). To prepare a $250 \mathrm{~g}$ sample of dry beans: (1) The beans were soaked in $750 \mathrm{ml}$ distilled water for 12-14 h, drained, placed in a thick-bottomed 2-liter stainless steel pot, and covered with cold distilled water $(1 \mathrm{~cm}$ above the level reached by the beans). (2) The pot was brought to a boil and the heat was then lowered to the minimum. (3) The beans were cooked with a lid on (but steam was allowed to escape); during the cooking 
process, the level of the water was controlled and cold distilled water was added several times to compensate for evaporation (but simmering was maintained at all times). The beans were kept covered with water at all times. (4) When they were done (this point was determined by the morphology, color, and texture of each variety), $2.5 \mathrm{~g} \mathrm{NaCl}$ was added. The cooked beans were maintained at $80^{\circ} \mathrm{C}$ for up to $2 \mathrm{~h}$ until the test was performed.

\section{Sensory analysis}

Samples were submitted to a panel consisting of 12 members who were previously trained over a 2-year period (Del Romero Castillo et al. 2008). Each sample was made up of $30 \mathrm{~g}$ of beans served on a small plate at a temperature of $70-80^{\circ} \mathrm{C}$ and was identified by three-digit codes chosen at random. All combinations of variety $\times$ location $\times$ year were tasted in duplicate, so ten sessions were performed in total (6 varieties $\times 2$ locations $\times 2$ years $\times 2$ replications $/ 5$ samples per session). In each session, the panelists tasted between 3 and 5 samples served simultaneously. All tasting sessions took place in individual booths meeting the standards set forth by the International Organization for Standardization (ISO International Standard 8589 2007).

The intensity of each texture attribute was quantified on a $10 \mathrm{~cm}$ semi-structured scale with the extremes labeled with corresponding descriptions, as described by Romero del Castillo et al. (2008) For seed-coat roughness, 0 represented a smooth seed coat like the reference Tolosa bean, and 10 represented a very rough seed coat like the reference Ganxet Montcau bean. For seed-coat perceptibility, 0 stood for extremely low perceptibility, like the Ganxet Montcau bean boiled with distilled water, and 10 stood for very high perceptibility, like the Ganxet Montcau bean boiled in water containing $200 \mathrm{ppm}$ of $\mathrm{Ca}$. For mealiness, 0 meant high creaminess like the Ganxet Montcau bean boiled in distilled water and 10 meant high mealiness like the Tolosa bean cooked in distilled water. For flavor, 0 represented no bean flavor and 10 stood for very intense bean flavor like Tolosa. Montcau is a medium-sized, white, flat, and very hooked bean of the Ganxet market class (Santalla 2001), while Tolosa is a medium-sized, black, and round bean of the Negro Brillante market class (Santalla 2001).
Culinary traits

We recorded the cooking time (time elapsed from when the water breaks a boil until the beans are considered cooked) and percentage of beans that remained whole after cooking for each sample (100 g cooled beans are drained for $5 \mathrm{~min}$; then the whole beans are separated from the broken ones and weighed to calculate the percentage of whole beans). The beans were considered cooked when they were soft enough to be eaten; this was determined by successive sampling by a trained person.

\section{Results}

\section{Significance of the ANOVA}

The variety effect was significant for all traits except flavor. The year effect was significant for all traits except seed coat roughness. The location effect was significant for all traits except flavor, and the panelist effect was significant only for flavor (Table 2). The interaction variety*year was significant for all traits except mealiness and flavor. The interaction variety*location was significant for all traits except seed coat perception and flavor, and the interaction variety*panelist was significant for seed coat roughness and flavor. The triple interaction variety*location*year was significant for all traits except flavor (Table 2).

Sensory and cooking attributes

Several significant changes in the sensory and culinary traits of the A25 line occurred during the breeding process to create a new set of lines (Table 3 ).

Xana and its derivate lines had a significantly rougher seed coat than A25 (Table 3). On the other hand, A2418 and A2806, directly derived from A25, were not significantly different from A25 in seed coat roughness (Table 3 ).

No significant differences in seed coat perceptibility were observed between A25 and Xana (Table 3); seed coat perception was higher in X1319 and X1358 than in A25, while it was lower in A2418 and A2806 than in A25 (Table 3).

Mealiness was lower in Xana than in A25, while the other new lines were not significantly different for this trait (Table 3). 
Table 2 Main significant results of the ANOVA for the six genotypes tested for six traits in two locations during 2 years

\begin{tabular}{lcccccc}
\hline Source & Seed coat roughness & Seed coat perception & Mealiness & Flavor & Cooking time & \% Whole seeds \\
\hline Variety & $<0.001$ & $<0.001$ & $<0.001$ & 0.4009 & $<0.001$ & $<0.001$ \\
Year & 0.9378 & 0.0014 & 0.0049 & 0.0213 & $<0.001$ & 0.0067 \\
Location & $<0.001$ & $<0.001$ & $<0.001$ & 0.3595 & $<0.001$ & $<0.001$ \\
Panelist & 0.1524 & 0.0925 & 0.7542 & 0.0031 & - & - \\
Var*year & 0.0003 & 0.0010 & 0.1119 & 0.5226 & $<0.001$ & $<0.001$ \\
Var*loc & 0.0022 & 0.1504 & $<0.001$ & 0.5153 & 0.0076 & $<0.001$ \\
Var*panelist & 0.0964 & 0.1131 & 0.0592 & $<0.001$ & - & - \\
Var*loc*year & $<0.001$ & 0.0195 & 0.0276 & 0.7838 & $<0.001$ & $<0.001$ \\
\hline
\end{tabular}

No changes in flavor were observed during the breeding process when the average of both locations and years was considered, but some lines had less flavor than A25 in Argüelles or Villaviciosa (Table 3).

Cooking time was significantly shorter in A25 than in all the new lines (Table 3), and A25 had a significantly higher percentage of whole seeds after cooking than all the new lines except A2418 (Table 3).

\section{Environment effects}

Seeds harvested in Villaviciosa scored higher in seed coat roughness and cooking time than those harvested in Argüelles. Furthermore, seeds harvested in Villaviciosa scored lower in seed coat perception, mealiness, and percentage of whole seeds after cooking than those harvested in Argüelles (Table 3).

Seeds harvested in 2006 had a more perceptible seed coat and less flavor, were mealier, needed more cooking time, and were more susceptible to breakage during cooking than those harvested in 2007 (Table 4).

\section{Discussion}

Genetic changes in sensory and culinary traits that occurred during the breeding process

The panelist effect and the interaction variety $\mathrm{x}$ panelist were significant for only flavor (Table 2); this confirms the panel's ability in discriminating.

In the obtainment of line A2418, only a backcross method was used to introgress the genes $I$ and $b c-3$. Theoretically, after 6 backcrosses and 3 selfing generations, $99.2 \%$ of the genome of A25 would have been recovered and only about $0.8 \%$ of the genome of the donor line BRB130 would remain in the new line, mainly linked to the introgressed genes (linkage group 2 with the $I$ gene and linkage group 6 with $b c-3$ gene). Similarly, line A1878 (Fig. 1) would have about $0.8 \%$ of the Sanilac genome, mainly linked to the $\mathrm{I}$ and $\mathrm{Co}-2$ genes (linkage groups 2 and 6, respectively). Line A2806, obtained by pyramiding the resistance genes from A2418 to A1878, would be expected to have more differences from A25 compared to A2418, because A2806 has introgressions from Sanilac and BRB130 (Fig. 1). Our results fit well with this hypothesis, as fewer differences respect to the A25 line were observed in A2418 than in A2806 (Table 5). Incorporating the donor line BRB decreased seed coat perception by $15 \%$ and increased the cooking time by $32 \%$ (Table 5). Incorporating the Sanilac donor line decreased seed coat perception by $11 \%$ and decreased the percentage of whole seeds after cooking by $27 \%$ (Table 5). Although we cannot elucidate whether these changes are due to the resistance genes introgressed or to other fragments of the donor lines' genomes, from the quality point of view some changes have been positive (decreased seed coat perception in both new inbreds respect to A25) and others have been negative (decreased percentage of whole seeds after cooking in A2518) (Table 5).

Likewise, important changes occurred during the obtainment of the Xana line. As this was a process of pedigree selection after crossing A25 with the V203 donor line, several fragments of the V203 genome other than those linked to the fin gene were probably introgressed in A25 (Fig. 1). As several selection criteria were considered, Xana would be expected to 
Table 3 Mean values of the traits for each variety for each year and for both years considered together

\begin{tabular}{|c|c|c|c|c|c|c|c|}
\hline Location and year & Variety & $\begin{array}{l}\text { Seed coat } \\
\text { roughness }\end{array}$ & $\begin{array}{l}\text { Seed coat } \\
\text { perception }\end{array}$ & Meal-iness & Flavor & $\begin{array}{l}\text { Cooking } \\
\text { time }\end{array}$ & $\begin{array}{l}\% \text { Whole } \\
\text { seeds }\end{array}$ \\
\hline \multirow[t]{8}{*}{ Argüelles + Villaviciosa $(2006$ + 2007) } & A2418 & 2.46 & 3.54 & 5.23 & 3.65 & 114 & 63.13 \\
\hline & A2806 & 3.25 & 3.07 & 5.28 & 4.00 & 112.85 & 46.84 \\
\hline & A25 & 2.72 & 4.16 & 5.06 & 4.41 & 86.65 & 63.76 \\
\hline & X1319 & 4.13 & 5.22 & 4.83 & 3.72 & 92.00 & 31.56 \\
\hline & $\mathrm{X} 1358$ & 4.89 & 4.88 & 5.11 & 4.10 & 114.33 & 39.44 \\
\hline & Xana & 4.11 & 4.05 & 4.36 & 4.25 & 123.78 & 33.02 \\
\hline & Mean & 3.59 & 4.15 & 4.98 & 4.02 & 107.28 & 46.29 \\
\hline & LSD (0.05) & 0.57 & 0.57 & 0.58 & 0.81 & 5.91 & 1.95 \\
\hline \multirow[t]{8}{*}{ Argüelles (2006 + 2007) } & A2418 & 1.45 & 4.49 & 6.46 & 3.69 & 163.5 & 79.61 \\
\hline & A2806 & 1.43 & 3.62 & 6.27 & 3.33 & 135 & 63.35 \\
\hline & A25 & 2.2 & 4.32 & 5.43 & 4.31 & 106.04 & 77.42 \\
\hline & X1319 & 2.65 & 5.76 & 5.03 & 4.13 & 104.5 & 35.83 \\
\hline & X1358 & 3.35 & 6.43 & 7.39 & 4.39 & 155 & 46.88 \\
\hline & Xana & 3.14 & 4.68 & 4.95 & 4.32 & 139.81 & 32.53 \\
\hline & Mean & $2.37 *$ & $4.88 *$ & $5.92 *$ & 4.03 & $133.98 *$ & $55.94 *$ \\
\hline & LSD (0.05) & 0.67 & 0.77 & 0.78 & 0.81 & 11.12 & 1.81 \\
\hline \multirow[t]{8}{*}{ Villaviciosa $(2006$ + 2007) } & A2418 & 2.95 & 3.06 & 4.64 & 3.64 & 93.59 & 56.31 \\
\hline & A2806 & 3.8 & 2.89 & 4.98 & 4.23 & 106.37 & 42 \\
\hline & A25 & 3.13 & 4.04 & 4.77 & 4.48 & 72.94 & 54.09 \\
\hline & X1319 & 4.89 & 4.95 & 4.73 & 3.52 & 85.75 & 29.42 \\
\hline & X1358 & 5.59 & 4.19 & 4.18 & 3.98 & 94 & 35.72 \\
\hline & Xana & 4.93 & 3.52 & 3.88 & 4.19 & 111.14 & 33.4 \\
\hline & Mean & $4.22 *$ & $3.78 *$ & $4.53 *$ & 4.01 & $93.97 *$ & $41.82 *$ \\
\hline & $\operatorname{LSD}(0.05)$ & 0.67 & 0.63 & 0.64 & 0.66 & 7.57 & 3.2 \\
\hline
\end{tabular}

Mean values followed by an asterisk were significantly different $(P \leq 0.05)$ in the overall ANOVA

differ considerably from A25. The results are in concordance with this prevision, as compared to A25, Xana had 51\% higher seed coat roughness, $14 \%$ lower mealiness, $43 \%$ higher cooking time, and $48 \%$ lower percentage of whole seeds after cooking (Table 5). Again, we cannot know whether these changes are due to the fin allele itself or to other introgressed genes.

From Xana to X1319, seed coat perception increased by $20 \%$ and cooking time decreased by $26 \%$ (Table 5). These changes should be attributable to the pleiotropic effect of gene $\mathrm{Co}-9$ or to the accompanying genes in linkage group 4.

From Xana to X1358, many further changes occurred: seed coat roughness increased by $19 \%$, seed coat perception increased by $20 \%$, mealiness increased by $18 \%$, cooking time decreased by $8 \%$, and the percentage of whole seeds after cooking increased by $19 \%$ (Table 5). Through the donor line
A1183, the donor line Sanilac would have provided the genes for the changes seen in X1358 (Fig. 1).

From the quality point of view, compared to the lines derived from A25 without introducing the fin allele, the resistant lines derived from Xana have a rougher seed coat that leads to a decrease in the brilliant white color typical of Faba, a more perceptible seed coat, a higher percentage of broken seeds after cooking, and longer cooking time (except for X1319) (Table 5).

It is difficult to attribute these changes to pleiotropic or linkage effects because backcrossing and genealogic selection were combined. As expected, fewer changes were observed when only backcross methods were used than when pedigree selection for several traits was used or when several backcross processes were pyramided to obtain a multiresistant line. In short, sensory and culinary traits are so 
Table 4 Mean values for each trait for each variety and year

\begin{tabular}{|c|c|c|c|c|c|c|c|}
\hline Location and year & Variety & $\begin{array}{l}\text { Seed coat } \\
\text { roughness }\end{array}$ & $\begin{array}{l}\text { Seed coat } \\
\text { perception }\end{array}$ & Mealiness & Flavor & $\begin{array}{l}\text { Cooking } \\
\text { time }\end{array}$ & $\begin{array}{l}\% \text { Whole } \\
\text { seeds }\end{array}$ \\
\hline \multirow[t]{8}{*}{ Argüelles + Villaviciosa (2006) } & A2418 & 1.87 & 4.18 & 5.46 & 3.48 & 145.25 & 65.06 \\
\hline & A2806 & 3.06 & 3.02 & 5.62 & 3.59 & 130.25 & 59.47 \\
\hline & A25 & 2.3 & 3.91 & 4.94 & 4.21 & 103.63 & 69.91 \\
\hline & X1319 & 3.78 & 5.3 & 4.83 & 3.6 & 94.75 & 30.54 \\
\hline & $\mathrm{X} 1358$ & 4.77 & 5.38 & 5.18 & 4.3 & 135 & 34.15 \\
\hline & Xana & 4.26 & 4.38 & 4.37 & 4.05 & 112.15 & 30.13 \\
\hline & Mean & 3.34 & $4.36^{*}$ & $5.07 *$ & $3.87 *$ & $120.17 *$ & $48.21 *$ \\
\hline & LSD (0.05) & 0.66 & 0.69 & 0.67 & 0.71 & 7.37 & 2.69 \\
\hline \multirow[t]{8}{*}{ Argüelles + Villaviciosa (2007) } & A2418 & 3.48 & 2.45 & 4.84 & 3.94 & 70 & 60.4 \\
\hline & A2806 & 2.92 & 1.87 & 3.87 & 4.65 & 91 & 38.76 \\
\hline & A25 & 3.17 & 4.43 & 5.18 & 4.63 & 70.67 & 57.97 \\
\hline & X1319 & 3.58 & 2.94 & 4.15 & 4.23 & 104.59 & 42.52 \\
\hline & X1358 & 3.8 & 2.28 & 4.28 & 4 & 88.27 & 63.3 \\
\hline & Xana & 3.7 & 2.74 & 3.21 & 4.77 & 110.64 & 37.67 \\
\hline & Mean & 3.44 & $2.78 *$ & $4.26 *$ & $4.37 *$ & $89.20^{*}$ & $50.10 *$ \\
\hline & LSD (0.05) & 0.69 & 0.64 & 0.73 & 0.7 & 7.47 & 2.98 \\
\hline
\end{tabular}

Means followed by an asterisk were significantly different from those of the other year $(P \leq 0.05)$

Table 5 Significant $(P \leq 0.05)$ changes in the sensory and culinary traits during the obtainment of the different varieties

\begin{tabular}{|c|c|c|c|c|c|c|}
\hline Breeding process & Seed coat roughness & Seed coat perception & Mealiness & Flavor & Cooking time & $\%$ Whole seeds \\
\hline A25 to $\mathrm{Xana}^{1}$ & $<(+51 \%)$ & $=$ & $>(-14 \%)$ & $=$ & $<(+43 \%)$ & $>(-48 \%)$ \\
\hline $\mathrm{A} 25$ to $\mathrm{A} 2418^{2}$ & $=$ & $>(-15 \%)$ & $=$ & $=$ & $<(+32 \%)$ & $=$ \\
\hline $\mathrm{A} 25$ to $\mathrm{A} 2806^{1+2}$ & $=$ & $>(-26 \%)$ & $=$ & $=$ & $<(+30 \%)$ & $>(-27 \%)$ \\
\hline A25 to $X 1319^{1+2}$ & $<(+52 \%)$ & $<(+25 \%)$ & $=$ & $=$ & $=$ & $>(-51 \%)$ \\
\hline $\mathrm{A} 25$ to $\mathrm{X} 1358^{1+2}$ & $<(+80 \%)$ & $=$ & $=$ & $=$ & $<(+32 \%)$ & $>(-38 \%)$ \\
\hline Xana to $\mathrm{X} 1319^{1}$ & $=$ & $<(+29 \%)$ & $=$ & $=$ & $>(-26 \%)$ & $=$ \\
\hline Xana to $\mathrm{X} 1358^{1}$ & $<(+19 \%)$ & $<(+20 \%)$ & $<(+18 \%)$ & $=$ & $>(-8 \%)$ & $<(+19 \%)$ \\
\hline
\end{tabular}

\footnotetext{
1 Pedigree selection
}

2 Backcross method

complex that even very few changes in the genome from backcrossing processes can lead to changes in their values.

Magnitude of the genetic changes with respect to environmental effects

As mentioned above, the changes that occurred during the breeding process are significant but so are the environmental effects (Tables 2, 3 and 4, and Fig. 2). The characteristics of the soil in Villaviciosa (less electrical conductivity, higher $\mathrm{P}$, lower $\mathrm{Ca}$, and higher cation exchange ability than in Argüelles) explain the lower seed coat perceptibility and lower mealiness of the beans cultivated there (Table 1). High soil $\mathrm{Ca}$ content favors the absorption of this mineral by the plant and its combination with the uronic acid in the seed coat, preventing its solubilization during cooking. Low soil $\mathrm{P}$ content is related with the $\mathrm{P}$ and phytic acid content in the seed; $\mathrm{P}$ in the seeds competes with uronic acids for combining with $\mathrm{Ca}$. Finally, high cationic exchange ability favors high protein content 


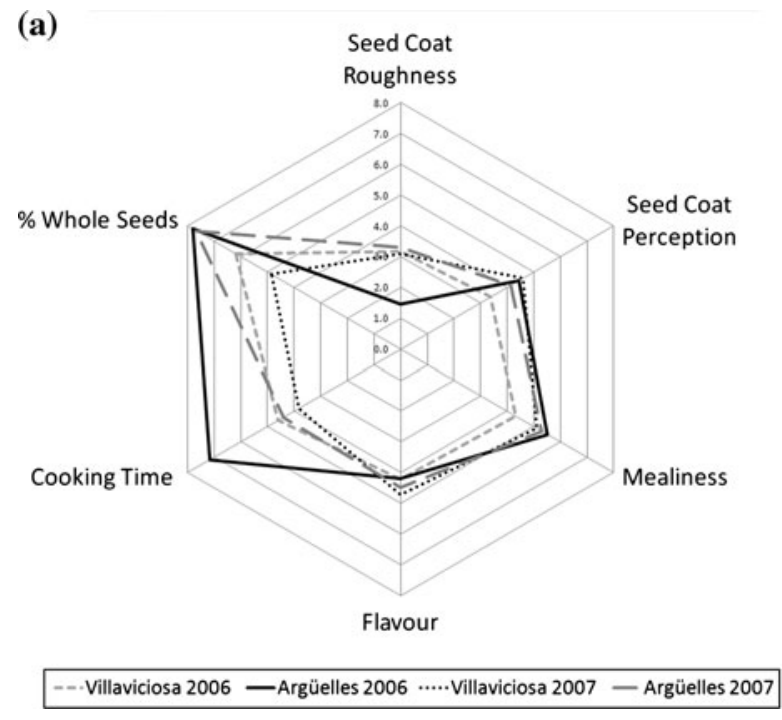

Fig. 3 Graphic representation of the different traits in the varieties, average of Arguelles and Villaviciosa 2 years (genetic effects) (a) and in the different combinations of location $\times$ year in the variety A25 (environmental effects) (b). Culinary traits have been transformed to a scale from 1 to 10 to facilitate

in the seed, which decreases mealiness (Florez et al. 2009; Galiotou-Panayotou et al. 2008; Kigel 1999; Casanas et al. 2006). We also observed significant differences between years for all the traits except seed coat roughness (Table 4). Compared to the beans harvested in 2006, those harvested in 2007 had a less perceptible seed coat and higher flavor, were less mealy, required shorter cooking times, and yielded a higher percentage of whole beans after cooking (Table 4). These differences are probably due to the difference in rainfall during the month of August in both locations. The lower rainfall in August 2006 represented an environmental stress for the growth and ripening of the seed that explains these findings.

The variations due to environmental effects observed in these 2 years and locations for the initial A25 variety are generally of the same magnitude as the differences due to the genetic components in the varieties derived from A25 (Fig. 3). However, this does not hold true for seed coat perceptibility, where $\mathrm{X} 1319$ and X1358 had high values outside the range defined by the environmental variation (Fig. 3). In Xana, X1319, and X1358 the percentage of whole seeds after cooking also differed significantly from A25 (Fig. 3).

Preliminary studies (unpublished data recorded in bean taste tests with untrained consumers) show that

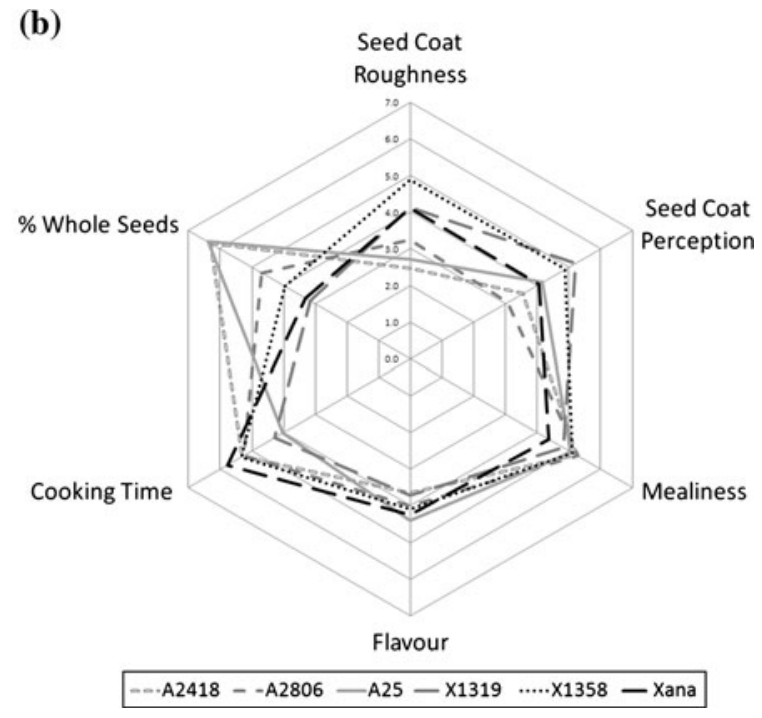

comparison with the sensory traits, which were originally recorded on a scale from 1 to 10: the percentage of whole beans after cooking was transformed using the formula $\mathrm{X} \backslash 100$ to $\mathrm{X} \backslash 10$ and the time required for cooking was transformed using the formula Xscal=(Xij/Xjmean $) * 5$

consumers tend to prefer the group formed by A25, A2806, and A2418, although the reasons for this preference respect to the group formed by Xana, $\mathrm{X} 1319$, and X1358 were not investigated (only a preference test was performed). Trained panelists' classify these differences as numerical changes related to well-defined attributes. According to consumers' preferences, both positive and negative changes have occurred in sensory traits during the breeding process. Although this is a first case of study, our results reveal the need to check sensory and culinary traits during the breeding processes and to include these attributes as selection criteria to ensure that the initial sensory properties of the recurrent line are not lost.

Acknowledgments This work was supported by grants RTA2005-00115-C02-01 and AGL2007-66563-C02-02 from the Ministry of Science and Innovation, Spain. E. Pérez-Vega received a fellowship salary from INIA (Madrid, Spain).

\section{References}

Aylesworth JW, Tu JC, Buzzell RI (1983) Sanilac BC6-are white bean breeding line. Hortscience 18(1):115

Bhattacharjee P, Singhal RS, Kulkarni PR (2002) Basmati rice: a review. Int J Food Sci Technol 37(1):1-12

Casanas F, Pujola M, del Castillo RR, Almirall A, Sanchez E, Nuez F (2006) Variability in some texture characteristics 
and chemical composition of common beans (Phaseolus vulgaris L). J Sci Food Agric 86(14):2445-2449. doi: $10.1002 /$ jsfa. 2638

Chaib J, Lecomte L, Buret M, Causse M (2006) Stability over genetic backgrounds, generations and years of quantitative trait locus (QTLs) for organoleptic quality in tomato. Theor Appl Genet 112(5):934-944. doi:10.1007/s00122-0050197-7

Del Romero Castillo RR, Valero J, Casanas F, Costell E (2008) Training, validation and maintenance of a panel to evaluate the texture of dry beans (Phaseolus vulgaris L.). J Sens Stud 23(3):303-319

Fehr W (1987) Breeding methods for cultivar. Soybeans: improvement, production and uses, 2a edn. American Society of Agronomy, Madison

Ferreira J, Campa A, Pérez-Vega E (2007) Nuevas variedades de judía tipo Faba Granja desarrolladas en el SERIDA: resultados de las evaluaciones morfológicas, agronómicas y de calidad. SERIDA KRK Ediciones

Florez A, Pujola M, Valero J, Centelles E, Almirall A, Casanas F (2009) Genetic and environmental effects on chemical composition related to sensory traits in common beans (Phaseolus vulgaris L.). Food Chem 113(4):950-956. doi: 10.1016/j.foodchem.2008.08.036

Galiotou-Panayotou M, Kyriakidis NB, Margaris I (2008) Phytase-phytate-pectin hypothesis and quality of legumes cooked in calcium solutions. J Sci Food Agric 88(2): 355-361. doi:10.1002/jsfa.2973

Guerrero L, Guàrdia MD, Xicola J, Verbeke W, Vanhonacker F, Zakowska-Biemans S, Sajdakowska M, Sulmont-Rossé C, Issanchou S, Contel M, Scalvedi ML, Granli BS (2009) Consumer-driven definition of traditional food products and innovation in traditional foods. A qualitative crosscultural study. Appetite 52(2):345-354

Hoberg E, Ulrich D, Gottwald J, Rosen A (2003) Environmental influences on the sensory quality of Asparagus officinalis L. In: Tijskens LMM, Vollebregt HM (eds) Proceedings of the international conference on quality in chains, vols 1 and 2 - an integrated view on fruit and vegetable quality. Acta horticulturae. International Society Horticultural Science, Leuven, pp 395-401

ISO International Standard 8589 (2007) Sensory analysisGeneral guidance for the design of test rooms. International Organization for Standardization, Geneva

Jin L, Lu Y, Shao Y, Zhang G, Xiao P, Shen S, Corke H, Bao J (2009) Molecular marker assisted selection for improvement of the eating, cooking and sensory quality of rice (Oryza sativa L.). J Cereal Sci 51(1):159-164

Kigel J (1999) Culinary and nutritional quality of Phaseolus vulgaris seeds as affected by environmental factors. Biotechnol Agron Soc Environ 3(4):205-209

Labuschagne IF, Schmidt K, Booyse M (2004) Fruit quality assessment in apple breeding progenies. In: Laurens $\mathrm{F}$, Evans K (eds) Proceedings of the XIth Eucarpia symposium on fruit breeding and genetics, vols 1 and 2. Acta
Horticulturae. International Society Horticultural Science, Leuven, pp 321-325

Lecomte L, Gautier A, Luciani A, Duffe P, Hospital F, Buret M, Causse M (2004) Recent advances in molecular breeding: the example of tomato breeding for flavor traits. In: McCreight JD, Ryder EJ (eds) Advances in vegetable breeding. Acta horticulturae. International Society Horticultural Science, Leuven, pp 231-242

Marsh HD, Paterson T, Seal AG, McNeilage MA (2003) Heritability estimates in kiwifruit. In: Janick J (ed) Genetics and breeding of tree fruits and nuts. Acta horticulturae. International Society Horticultural Science, Leuven, p 221

Mendez-Vigo B, Rodriguez-Suarez C, Paneda A, Ferreira JJ, Giraldez R (2005) Molecular markers and allelic relationships of anthracnose resistance gene cluster B4 in common bean. Euphytica 141(3):237-245. doi:10.1007/s10681005-7075-x

Menezes JR, Dianese JC (1988) Race characterization of Brazilian isolates of colletotrichum-lindemuthianum and detection of resistance to anthracnose in Phaseolus-vulgaris. Phytopathology 78(6):650-655

Oraguzie NC, Whitworth C, Fraser J, Alspach PA, Morgan CGT (2003) First generation of recurrent selection in apple: estimation of genetic parameters. In: Janick J (ed) Genetics and breeding of tree fruits and nuts. Acta horticulturae. International Society Horticultural Science, Leuven, pp 213-220

Perez-Vega E, Paneda A, Rodriguez-Suarez C, Campa A, Giraldez R, Ferreira JJ (2010) Mapping of QTLs for morphoagronomic and seed quality traits in a RIL population of common bean (Phaseolus vulgaris L.). Theor Appl Genet 120((7):1367-1380. doi:10.1007/s00122-010-1261-5

Santalla M dRA, Voysest O (2001) European bean market classes. In: Amurrio M, de Ron AM, and Santalla M, (eds), Catalogue of bean genetic resources Fundación Pedro Barrié de la Maza/PHASELIEU-FAIR-PL97-3463-MBGCSIC:79-94

SAS Institute Inc. (1999) SAS/STAT ${ }^{\circledR}$ User's Guide, Version 8. SAS Institute Inc. Cary

Schonhof I, Krumbein A, Bruckner B (2004) Genotypic effects on glucosinolates and sensory properties of broccoli and cauliflower. Nahr-Food 48(1):25-33. doi:10.1002/food.200300 329

Singh S (1982) A key for identification of different growth habits of Phaseolus vulgaris L. Annu Rep Bean Improv Coop 25:92-94

Van ruth SM, Roozen JP, Posthumus MA (1995) Instrumental and sensory evaluation of the flavor of dried french beans (Phaseolus-vulgaris) influenced by storage-conditions. J Sci Food Agric 69(3):393-401

Voysest O (2000) Mejoramiento genético del frijol (Phaseolus vulgaris L.) : Legado de variedades de América Latina 1930-1999. Centro Internacional de Agricultura Tropical (CIAT), Cali 